\title{
Rusya Federasyonunda Gençlerin İşgücü Piyasasındaki İşsizlik ve İstihdam Sorunları
}

\author{
Unemployment and Employment Problems in The Labor Market of Youth in The Russian Federation
}

\author{
Akif ABDULLAH \\ Dr. Ö̆rr. Üyesi, Afyon Kocatepe Üniversitesi, \\ Emirda ğMYO, aabdullah@aku.edu.tr \\ https://orcid.org/0000-0001-8750-3783
}

Makale Başvuru Tarihi: 30.11.2020

Makale Kabul Tarihi: 17.12.2020

Makale Türü: Araştırma Makalesi

\begin{abstract}
Anahtar
Kelimeler:

Genç Çalışanlar,

İssizlik,

Istihdam,

İsgücü Piyasası,

Mesleki Ĕ̈itim,

Rusya Federasyonu ekonomik durum sebebi ile modern işgücü piyasasında birçok sorunla mücadele etmek durumunda kalmıştır. Ayrıca ekonominin yeniden yapılandırılması, işsizliğin büyümesi üzerinde etkiler yaratmaktadır. Artan rekabet koşulları altında, üreticiler yeni teknoloji ve işçi örgütlenme yapılarına uyum sağlamaya çalışırken zorlanmaktadırlar. Ancak bu durum üretim karlılığında artışa neden olmakla beraber diğer yandan işçi çıkarmalarına neden olmaktadır. Bu durumdan en çok etkilenen kesim ise gençlerdir. İşü̈cü piyasasında gençlerin işsizlik ve istihdam sorunları sadece Rusya'da değil, başta AB ülkeleri olmakla, gelişmiş ülkelerde bile en önemli sorunlardan biri olmaya devam etmektedir. Genç çalışanlar sosyo-ekonomik değişikliklere en hızlı şekilde tepki veren gruplar arasında yer almaktadırlar. Gençlerin ilk defa işe girdiklerinde karşılaşmış oldukları mesleki bilgi eksikliği, deneyim yoksunluğu ve bu gibi diğer zorluklar, genç işsizliğinin artması sorununun en temel nedenlerindendir. Çalışmamızda Rusya Federasyonu'nda gençlerin işgücü piyasasındaki durumları incelenmiştir. Bununla beraber, işsizlik ve istihdam sorunlarının giderilmesi için, çözüm yolları önerilmiştir.
\end{abstract}

Keywords:
Young Workers,
Unemployment,
Employment,
Labor Market,
Vocational
Education,

\section{ÖZET}

\section{ABSTRACT}

The Russian Federation has had to struggle with many problems in the modern labor market due to the economic situation. In addition, restructuring of the economy has effects on the growth of unemployment. Under increasingly competitive conditions, producers have difficulties while trying to apply new technology and worker organization structures. However, this condition causes an increase in production profitability, on the other hand, it causes workers to be fired. Young people are the most affected by this condition. Unemployment and employment problems of young people in the labor market continue to be one of the most important problems not only in Russia but also in developed countries, especially in EU countries. Young workers are among the groups that react quickly to socio-economic changes. The lack of professional knowledge, experience and other such difficulties that young people face when they first find a job are the main reasons for the problem of increasing youth unemployment. In our study, the situation of the youth in the labor market in the Russian Federation was examined. In addition, recommendations have been made to overcome unemployment and employment problems. 


\section{GIRISS}

Günümüzde Rusya Federasyonu resmi istatistikleri işgücü piyasasının gerçek durumunu tam olarak yansıtmamakla birlikte yalnızca iş borsasına (istihdam bürolarına) kayıtlı çalışanlar yer almaktadırlar. İşgücü piyasasında birçok insan iş borsalarının hizmetlerini kullanmanın anlamsız olduğunu ve bu hizmetle iletişim kurmanın sosyal statüleriyle uyuşmadığını, hatta sonraki iş kariyerlerini olumsuz etkileyebileceğini düşünmektedirler.

İstihdam bürolarına 16 yaşın altındaki kişiler, emekliler, hükümlüler vb. kayıt yaptırmamaktadırlar. Çoğu zaman insanlar bu bürolara istihdam olanaklarının sınırlı olduğunu varsaydıklarından başvurmamaktadırlar. Rusya'da iş arayanların sadece üçte biri kendi imkânlarıyla iş bulmuş, iş bulamayanların yarısı ise istihdam hizmetleri bürolarına başvurmaktadırlar.

İşçi borsalarına kayıtlı olanların neredeyse yarısı iş aramamaktadırlar. Bu insanların çoğu kayıt dışı çalışmaktadırlar. Ancak bu kişilerin iş borsalarında kalmalarının nedeni yardım olup, sadece nadir durumlarda da olsa istihdam hizmetinin yardımıyla uygun bir kalıcı iş bulmayı ummaktadırlar. İş borsalarına kayıtlı olanlar arasında genellikle çalışmak istemeyenler ve yıl boyunca pratikte her hangi bir çalışma sonucu kazanılmamış gelir elde eden insanlar bulunmaktadır. Nüfus içindeki gerçek işsizliğin artış nedeni olarak, iş arayan ve kayıtlı olmayanların sayısı ile resmi istatistiklere göre iş aramayan kayıtlı vatandaş sayısındaki sonuçlara göre belirlenmektedir.

Rusya Federasyonu Hükümeti'nin 29 Kasım 2014 tarihli N 2403-r sayıl1 "2025 yllına kadarki dönem Rusya Federasyonu Devlet Gençlik Politikası" kararına göre Gençler - yaş özellikleri, sosyal statü ve belirli ilgi alanları ve değerleri ile karakterize edilen sosyo- demografik bir gruplardır. Bu gruplar, 14 ila 30 yaşları arasındaki kişiler olup, ancak bazı durumlarda ise, Rusya Federasyonu'nun kurucu kuruluşlarının yasal düzenleyicileri tarafından belirlenen 35 ve daha fazla yaşı olan kişileri de içerebilmektedir.

Uzmanlık alanlarında iş deneyimi olmayan ancak üniversite eğitim almış ve teknik okul mezunlarına talep olmaması, işgücü piyasasında ayrımcılık anlamına gelmektedir. 18 yaşın altında olup, orta öğretim okullarında ve meslek okullarındaki öğrencileri genç gruptaki kişileri temsil etmektedirler. Bu gruptaki gençler çoğu durumda istihdam edilmemektedirler. Bununla birlikte, Rusya nüfusunun yaşam standartlarındaki önemli bir düşüş, bu gruptaki insanların görüşlerini ve yaşam şekillerini değiştirmiştir. Bu gruptakilerin birçoğu her ne şekilde olursa olsun para kazanmaya çalışmaktadırlar.

Gençlerin iş arama merkezlerine başvurma olasılıkları diğer yaş gruplarındaki insanlara göre daha düşük olduğundan, gençlerin işgücü piyasasındaki konumunu gerçekten gösteren verileri analiz etmek ve karşılaştırmak oldukça karmaşı bir problem olmaktadır. Ek olarak, resmi kayıtlar esas olarak ekonominin kamu sektöründe tutulmakta ve gizli işsizlik hiçbir şekilde kayıt altına alınmamaktadır, bu da üretimdeki düşüşü önemli ölçüde artırmaktadır. Bu nedenle, Rosstat (Rusya Devlet İstatistikleri) ve Federal Çalışma ve İstihdam Servisi tarafından sağlanan veriler, işgücü piyasasındaki mevcut durumu tam olarak yansıtmamaktadır.

Günümüzde ergenlerin istihdam durumu, yani araba yıkamak, broşür dağıtmak gibi serbest mesleklerde çalışmaları endişe verici durumdadır. Vasıfsız ergenler için işgücü piyasası çok dar kapsamlıdır. KFC veya McDonald's gibi şirketler, iş arayan veya çalışmak isteyen tüm gençler için para kazanma firsatı sağlayamamaktadır. İşgücü piyasasındaki istikrarsızlık, piyasa koşullarına uyum sağlayamayan büyük kuruluşlardan ve hükümet yardımlarının yetersizliğinden kaynaklanmaktadır. Bu tür organizasyonlar arasında metalürji, hafif sanayi, tekstil endüstrileri vb. yer almaktadırlar.

Rusya'daki işgücü piyasasında aktif nüfus içerisindeki kadınlar 16 ila 55 yaş arası, erkekler ise 60'a kadar olan kişileri temsil etmektedirler. Nüfusun çoğunluğu ücretli işçiler oluşturmuş olup, bunlar toplam işgücünün yaklaşık \%90'ını oluşturmaktadırlar. Geri kalanlar ise serbest mesleklerdeki ve bireysel girişimcilerdir. İstihdam edilenlerin arasında hizmet sektörü çalışanları en yüksek orana sahiptirler. İşgücü piyasası yapılanma türlerinden biri de demografik özelliklere göre bölünmesidir;

1. Genç işgücü piyasası.

2. Emeklilerin veya emeklilik öncesi yaştaki kişilerin işgücü piyasası.

3. Kadın işgücü piyasası.

Rusya'da genç işgücü piyasasındaki durum oldukça kritik olup, bozulma eğilimleri ile karakterize edilmektedir. Gençliğin işgücü piyasasındaki durumun analizi iki önemli koşul tarafından belirlenmektedir. Birincisi, gençler 
Rusya'nın çalışma çağındaki nüfusunun yaklaşık üçte birini oluşturmaktadırlar ve ikincisi onlar ülkenin geleceğidirler. Son verilere göre, Rusya'da 39,6 milyon genç vatandaş olup, bu da ülkenin toplam nüfusunun $\% 27$ 'sini oluşturmaktadır.

Uzmanlar, işgücü piyasasındaki mevcut durumun gençleri oldukça zor koşullara soktuğunu söylemektedirler. Örneğin, daha önce dağıtım sistemine göre eğitim kurumlarından mezun olanların alınan uzmanlık alanında istihdamı garanti edilmekteydi, şimdi ise iş tecrübesi olanları daha yüksek ve prestijli hale getirmektedir.

18 ve 24 yaşları arasındaki gençler, halen yüksek öğrenim kurumlarında eğitim alan veya eğitimlerini tamamlayan öğrenciler ve gençlerdir. Onlar gerekli mesleki deneyime sahip olmadıkları için işgücü piyasasına giren en savunmasız grupları oluşturmaktadırlar. İşsizlerin \%24,6'sını iş tecrübesi olmayanlar, iş tecrübesi olmayan işsizlerin de \%15,2'si 15-19 yaş arası, \%49,4'ü - 20-24 yaş arası, \%16,6 - 25-29 yaş arası gençlerden oluşmaktadır (Korçagina, 2016:1-11).

Gençler işgücü piyasasındaki değişikliklerden tüm yaş gruplarından daha fazla etkilendikleri için modern işgücü piyasasının bir göstergesi olarak adlandırılabilmektedirler. Gençlerin işgücü potansiyelinin yetersiz kullanılması, özellikle gençler için en az cazip olan sektörlerde, işgücü kaynaklarının yenilenme oranında bir düşüşe neden olmakla birlikte tüm ekonominin ve bir bütün olarak toplumun gelişimini olumsuz etkilemektedir.

\section{GENÇLERİN İŞGÜCÜ PIYASASINDAKI YERİ}

Gençlerin toplumdaki konumu maddi güvenlik seviyesi, profesyonel alanda kendini gerçekleştirme firsat, eğitim alma, kariyer yapma ve sivil haklarını ve sosyal güvencelerini sağlama gibi bir dizi nesnel ve öznel faktör tarafindan belirlenmektedir. Genç işsizliği ise olumsuz sonuçların özel şiddeti nedeniyle nüfusun istihdam sorunları düşünüldüğünde öne çıkmaktadır (Semenova, 2016:27).

Genç istihdamıyla ilgili sorunları analiz ederken iki ana yaklaşım ayırt edilmektedir. Birincisi, istihdamın dar bir yorumu şeklindedir. Bu açıdan istihdam, esas olarak işe almaya ve işsizliği azaltmaya yönelik tedbirlerdir. İkinci yaklaşımda ise, istihdam çok daha geniş bir biçimde karmaşık ve sistemik bir sosyal sorun olarak ele alınmıştır. Çözümü, daha geniş sosyal görevleri, yani gençlerin yeteneklerini tam olarak geliştirmelerini, hayatta bir yer bulmalarını, mesleklerini bulmalarını sağlamaktadır (Gorşkov, 2018:2-5).

Gençlerin istihdamı karmaşık bir sosyal sistem olarak düşünüldüğünde, içindeki temel yapısal unsurları vurgulamak gerekmektedir. Bu unsurlar şunları içermektedir: birincisi, gençlerin gelecekteki bir mesleğin bilinçli bir seçimine hazırlanması; ikincisi, ilgili mesleğe hâkim olmak; üçüncü ise iş arama ve istihdam prosedürü; dördüncü olarak da, iş yerinde gençlerin adaptasyonu ve işgücü sosyalleşmesidir (Kozlova, 2002: 80-95).

Gençlerin maddi ihtiyaçlarının karşılanma seviyesi açısından ortaya çıkan keskin sosyal farklılaşma, gençlerin daha prestijli ve finansal olarak güvenli iş türlerine sahip olma şanslarında da eşitsizliğe yol açmıştır. Genç kuşak için bu şansların eşitliğini sağlamaya çalışması gereken devlet, ne yazık ki henüz bu sorunla ilgilenmemektedir. Devletin ekonomik, sosyal ve hukuksal politikasının tamamında köklü bir değişiklik olmadan bu konudaki durumu değiştirmek mümkün değildir. Bu arada, bireyin gelişimine katkı sağlayan en önemli sosyal değer olan iş (çalışma), vicdanlı çalışmaya yönelik olumsuz bir tutum oluşturan temel zemindir. $\mathrm{Bu}$ bakımdan şu gerçek dikkat çekicidir: Devlet gençlik politikasında temel öncelikler arasında emek konularıyla ilgili bir yön bulunmamaktadır (Bobkov, 2014:23-55).

Bugün toplumun ve devletin görevi, gençlerin faaliyetlerini kamu çıkarlarına ve devlet kalkınmasının çıkarlarına yönlendiren gençlik kamu derneklerine çok yönlü destek sağlaması gerekmektedir. Gençlere boş zamanları organize etme ve sağlama alanındaki devlet gençlik politikası, gençlerin ve çocukların sağlıklı bir yaşam tarzı, boş zamanlarının olumlu geçirmeleri için gerekli ideolojiyi oluşturmalıdır. Gençlik çalışmasının ana yönlerini koordine etmek ve geliştirmek için, gençlik çalışmaları yönetiminin yapısını federal düzeyden belediye düzeyine geliştirmek gerekmektedir. Gençliğin işgücü piyasasındaki durum oldukça gergindir. Bu yöndeki devlet politikası net bir şekilde yürütülmemektedir. Toplumun entelektüel potansiyelinin yeniden üretilmesi ve desteklenmesinin durmasına ve kitlesel genç işsizliğinin başlamasına izin verilmemesi gerekmektedir (Bateneva, 2014:36).

Dolayısıyla, işsizlik, ekonomik olarak aktif nüfusun bir parçası olan, iş yapmak için çabalayan ve çalışmaya istekli, ancak iş bulamayan kişilerin ülkedeki varlığı ülkenin sağlıklı, çalışabilir nüfusu için geçici bir iş eksikliğidir. İşsizlik, işgücü talebinin üzerinde işgücü arzının fazlalığı ile karakterize edilir. Uluslararası Çalışma Örgütü'nün (ILO) standartlarına göre işsizler, 15-75 yaşları arasındaki ekonomik olarak aktif, işsiz, iş arayan ve 
belli bir süre içinde çalışmaya hazır olan nüfusu oluşturmaktadırlar (Kozlova, 2002:101-110).

Oluşum nedenlerinden dolayı, işsizlik türlerini ayırt etmek ve sınıflandırmak gerekirse; Yapısal, Sürtünmeli, Döngüsel, Gizli, Mevsimsel, Bölgesel (bazı kaynaklarda ise Döngüsel, Doğal, Yapısal, Sürtünme, Gizli, Mevsimsel, Gönülliü, Teknolojik işsizlik türleri) olmaktadır.

Ayrıca, Rusya Federasyonu işgücü piyasasındaki gençlik kesimindeki, üretimde kalifiye işçi sıkıntısı ile karakterize olan zor duruma, uzmanların eğitim kurumlarında eğitildiği işgücü piyasasının talep ettiği meslekler ve uzmanlıklar arasındaki dengesizliğe dikkat edilmelidir. Eğitim kurumlarında genç uzmanlar için gerekli temel deneyimi elde etmek için staj organizasyonu, artan bir hızda daha az etkili hale gelirken, eğitim ile işgücü piyasasının talebi ve ekonomi arasındaki uçurum giderek artmaktadır (Bobkov, 2014:23-55).

Mezunların, genç uzmanları tecrübesizliği bir iş bulmanın son derece zor olduğunun (deneyim ancak iş bularak kazanılabileceğinin) farkındalı̆̆ sayesinde öğrenciler üniversitedeki eğitimleri sırasında bile çeşitli şekillerde iş bulmaya çalışmaktadırlar. Bu eğilim, mesleki ve normal eğitim seviyelerinde bir düşüşe yol açmaktadır. Bu bağlamda, yenilikçi bir ekonominin oluşumu, endüstrilerde dijital dönüşüm, dinamik olarak değişen dünyanın talep ve gereksinimlerine hızlı adaptasyon için artan ihtiyaçlar, dinamik ekonomik büyüme ve toplumun sosyal kalkınmasının temeli olarak, bir kalkınma faktörü, vatandaşların refahı ve ülke güvenliği için orta ve yüksek mesleki eğitim sisteminin modernizasyonunu gerektirmektedir (Semenova, 2016:38).

Ekonomide devlet düzenlemelerinin temel görevlerinden biri genel durumun belirlenmesi ve onun geliştirilmesidir. Toplumsal ve sosyo-ekonomik alanın konumu, emek kaynaklarının yeniden üretimi, miktarı ve kalitesi, üretici güçlerin bilimsel ve teknolojik gelişme düzeyi gibi süreçlerle belirlenmektedir. Günümüz işgücü piyasasındaki durum çok çelişkili olup: yüksek bir işsizlik oranının varlığı göz önüne alındığında, aynı zamanda profesyonel olmayan ve vasıfsız personel sorunu da bulunmaktadır (Dunaeva, 1998:75-91).

Sonuç olarak, devlet işgücü kaynaklarının kalitesini iyileştirme sorununu çözmeye vurgu yapmaktadır. Ancak genç işgücü piyasasındaki durum, bu sorunun çözümünde özel bir yer tutmaktadır. Nitekim bugün asıl sorun tam olarak gençlerin istihdamıdır. Gençler bir yandan daha aktif, teknoloji alanında daha ileri, ancak diğer yandan da sosyal olarak korunmamaktadırlar. Bir iş bulduklarında ise birçok sorunla karşılaşmaktadırlar. Bu sorunların başlicaları (Brusyanina, 2010:126-128);

- İş ve öğrenimi aynı anda birleştirmenin zorluğu,

- İş deneyimi eksikliği,

- İşgücü piyasasındaki ayrımcılık.

Çoğu işveren gençlerin çalışma hayatındaki becerilerin eksikliği, iş kolektifinde karşılıklı anlayışsızlık, sosyalleşmenin düşük bir seviyesi gençlerde bu tür özellikleri olumsuzluk olarak görmekte ve değerlendirmektedirler (Brusyanina, 2010:126-128).

Rusya'da her yıl eğitim seviyesi artmakla birlikte giderek daha fazla genç uzman ve çalışan ortaya çıkmaktadır. Ancak paradoks, profesyonel ve mesleki uzman işçilerin sayısının az ve yetersiz olmasıdır. Analistlere göre bu durum, işverenin gerçek ihtiyaçlarının yanlış hesaplanmasından kaynaklanmaktadır. Bugün mezunların yaklaşık \%53'ü eğitim aldıkları meslekte çalışmakta olup, geri kalan \%47'lik kesim ise iş deneyimi eksikliği nedeniyle uzmanlık alanlarında çalışamamaktadırlar (Kolmakova, 2016: 35-70). Ancak genç işgücü piyasasının özelliklerine göre;

1. Gençlere yönelik işgücü piyasası, arz ve talep istikrarsızlı̆̆ ile karakterizedir. Özellikle bireyin gelişimi için sosyo-kültürel ve politik koşulların değişkenliği ile bağlantılı olarak gençlerin ve genç uzmanların artan sosyal sorunları ve ardından gençlerin kendi kaderini tayin etme sorunu nedeniyle karmaşıklaşmaktadır.

2. Genç işgücü piyasası, diğer yaş gruplarına kıyasla son derece düşük rekabet gücü ile karakterize edilmektedir, yani genç uzmanlar işlerini kaybetme veya iş bulamama konusunda en büyük riske sahiptirler.

3. Açık ve gizli boyutlar içeren genç istihdamı hiçbir yerde okumayan ve çalışmayan gençlerin sayısını artırmaktadır.

4. Gençlere yönelik işgücü piyasasının çok sayıda varyasyonu vardır. Bu, şu şekilde gelişmekte olan durumla açıklanmaktadır: mezun olduktan sonra, kurumların genç uzmanları-mezunları, belirli uzmanlıklara talebin olmadığı bölgesel pazara girmektedirler. Onlar için tek çıkış yolu bir iş bulup, 
deneyim kazanmaktır.

5. Yaş sınırlamasına dayalı ayrımcılığın yanı sıra kadın (cinsiyet) ayrımcılığı da vardır. Bu, kadınların çoğunluğu oluşturması, ancak işverenlerin işe alırken erkek uzmanların tercih ettikleri görülmektedir.

Yukarıdakilerden, işgücü piyasasındaki gençlerin temel zorlukları dikkate alındığında: genç nesil için işverenlerin ihtiyaç duyduğu iş deneyimi ve iş becerilerinin yanı sıra bunu elde etmenin zorluğu, genç işsizliği, daha adil olma, cinsiyete karşı ayrımcılık sorunu, arz ve talep dengesizliği sorunu işgücü piyasasında devam etmektedir (Korçagina, 2014:315-340).

Gençler genellikle iş aramada aktif bir pozisyondan mahrumdurlar. Bu da yeterli sayıda iş firsatına erişimi kullanamadıkları anlamına gelmektedir. Bu durum aynı zamanda işgücü piyasasındaki zorlu ve karmaşık sorunların olduğu bir ortamda olma isteksizliğinden de kaynaklanmaktadır. İşgücü piyasasındaki durumun önemli bir göstergesi işsizlik oranının dinamikleridir. İstatistikler, tüm işgücü piyasasında olduğu gibi genç işgücü piyasasındaki tüm durumu tam olarak yansıtmaktadır. Gençlerin işgücü piyasasında kaydolma olasılıkları diğer yaşlardaki insanlara göre daha düşüktür. İstatistikler, yalnızca işgücü piyasasının resmi kısmının gelişme eğilimlerinin değerlendirilmesine izin vermektedir. Sonuç olarak, gizli işsizlik de dâhil olmak üzere, istihdam alanındaki Rusya pazar ilişkilerinin özellikleriyle ilişkili tüm yeni fenomenler dikkate alınmamaktadır (Soroçaykin, 2012:160-185).

Genç nüfus işgücü piyasasının en önemli özelliklerinden biri de gizli işsizliğin mevcut olmasıdır. Nedeni ise piyasada faaliyet gösteren özel ve kamu kuruluşlarındaki şirketlerin reformlarda ilk işten çıkarılacaklar listesinin başında olmalarından dolayı risk altındadırlar. Gençlerin çoğu için üretken emeğin düşük prestiji sosyal karamsarlığa yol açmıştır. Bundan dolayı bu gençler tatmin edici, iyi maaşlı bir işe sahip olma firsatını görememektedirler. Öncelik, üretimde anlamlı çalışmaya değil, herhangi bir yolla yüksek maddi fayda elde etmeyi amaçlayan düşük yoğunluktaki çalışmaya ağırlık verilmiştir. Doğal olarak bu durum ülke ekonomisinin canlanmasına katkıda bulunmaktadır. Bununla birlikte, son zamanlarda ilginç bir eğilim olmuştur: gençler artık kendi küçük işletmelerini açmaya hazırdırlar (internet satışları, BT [Bilgisayar Teknolojileri] alanı, hizmet sektörü, turizm vb). Hükümet de bu durumda küçük işletmeler gibi girişimleri desteklemeli, gençler de bunu sonucunda kendileri yeni iş yerleri (alanları) yaratabilecek ve işsizler ordusunu yenilemeyeceklerdir. Bu nedenlerle, gençler işgücü piyasasında oldukça savunmasız bir kategoride yer almaktadırlar (Stigliç, 2005:420).

Modern işgücü piyasasının unsurlarından biri olarak işsizlik çalışmasının önemi, emek talebi ile arz arasındaki arz eksikliğini belirlemektedir. Bir bütün olarak piyasa mekanizmasının en önemli bileşenlerinden biri olan işgücü piyasası, işçi, işveren, devlet tarafları arasındaki bir sosyo-ekonomik ilişkiler kompleksidir. Bu ilişkiler, çalışan eğitimi, iş ilişkileri ve çalışanların doğrudan üretim sürecinde kullanılması gibi hususları etkilemektedir. Piyasa ekonomisini ve özellikle işgücü piyasasını karakterize eden önemli bir fenomen, işgücü arzı talebi aştığında işgücü arzı ve talebi arasındaki ilişkiyi temsil eden işsizlik ortaya çıkmaktadır (Sulakşin, 2016:90-68).

İşsizlerin sayısını belirleyen en önemli kriter 15 ila 75 yaşları arasındaki aktif bir nüfustur. Bununla birlikte diğer kriterler içerisinde bir işi olmayan yetişkin vatandaşları, aktif olarak iş aramaya katılan ve çalışmaya başlamaya hazır vatandaşları da sayabiliriz. İşsiz sayısının dışında tutulanlar ise yaş veya sağlık nedenleriyle çalışamayacak durumda olan vatandaşlar ve belirli nedenlerle bir işe başvurmayanları (ev hanımları, vb.) örnek verebiliriz (Yureviç, 2012:20-45).

İşsizliğin nedenleri ile ilgili olarak, işgücü piyasasındaki işgücü kaynaklarının doğal hareketi ile ilişkili olan herhangi bir ekonomik sistemde belirli bir düzey çalışan ve işsiz nüfus gruplarının varlığını öne süren modern görüşe göre farklılıklar göstermektedir. Yüksek işsizlik oranlarının, büyük işsizlik yardımlarının ödendiği ülkelerde daha yüksek olduğu ve bunun da en iyi iş seçeneğini bulma ve bekleme süresini artırdığı sıklıkla belirtilmektedir. Çoğunlukla, sağlıklı vatandaşlar, olası yardım alma süresi içinde kasıtlı olarak işsiz kalmaktadırlar (Luçankin, 1997:48).

İşsizliğin bir başka nedeni de ülkedeki ücret seviyesinin çok düşük ve sabit olması olabilir. Bu nedenle işgücü piyasasında arz ve talebi senkronize etmek için esnek bir ödeme sistemi adaptasyonu kullanmak gereklidir. Gerçek uygulamada ise, esas olarak sabit, esnek olmayan, geleneksel zaman ve parça başı ücret formları ve sistemleri kullanılmaktadır. Düşük ücretlerden kaynaklanan işsizliğe beklenti işsizliği denir. Çünkü bunun ortaya çıkması, işgücü arzının sabit bir ücret düzeyinde talebe hâkim olmasıyla ilişkilidir (Ruçkin, 2000:26-45).

Rusya'da, ekonomi piyasasında tarihin en kritik yılları 1992-2000 yılları olmuştur. Daha sonra ise işsizlik oranı kademeli olarak düşmeye başlamıştır. 2018 y1lına gelindiğinde ise işsizlik \%4,6 olmuştur. Rosstat'a göre, Ocak 2019'da Rusya'da toplam işsiz sayısı, Aralık 2018'e göre 31 bin kişi azalarak 3 milyon 667 bin kişiye ulaşmış ve işsizlik oranı \% 4,9 olmuştur. 
Gençlerin emek istekleri ile onları tatmin etme olanakları arasında büyüyen uçurum bugün Rusya işgücü piyasasının günümüz temel problemlerinden birini oluşturmaktadır. ILO metodolojisine göre 2018 y1lında Rusya Federasyonu'nda toplam işsiz sayısı 3,5 milyon kişi olurken, 15-24 yaş arası gençlerin toplam işsiz sayısı içindeki pay1 \%22,8 olmuştur (http:www.gks.ru/). Bu alanda çeşitli uzmanların analizine göre, Rusya Federasyonu'nda 15-24 yaş arası işsizlerin payı 30-49 yaşları arasındaki işsizlerin payına göre önemli bir fazlalık oluşturmaktadır. Mevcut makroekonomik kriz ve jeopolitik türbülansın gerçekleri göz önüne alındığında, en yüksek risk grubundakiler, çeşitli finans şirketlerinde ve bankalarda iş bulup çalışan gençlerdir. Daha yalın bir ifade ile personel azaltma sürecinde ilk işine son verilecekler onlardır.

Gençler arasında mevcut yüksek işsizlik düzeyinin diğer nedenleri arasında şunlar yer almaktadır (Sulakşin, 2015:115);

1. Eğitim kurumlarından yeni mezun olmuş genç uzmanları mesleklerine uygun iş yerlerine atamak için bir sistemin olmamas1.

2. Şu anda işgücü piyasasında talep edilen uzmanlar ve çeşitli eğitim kurumları tarafından hangi alanlarda eğitilen profesyoneller hakkında veri sistemi mevcut değildir.

3. Gençlerin yetişkin yaşamına adaptasyonu için gerekli olan maliyetlerin önemli ölçüde artması ve potansiyel işverenlerin riskleri, genç nüfusun rekabet edebilirlik seviyesinde bir azalmaya yol açmaktadır.

4. İşverenlerin çoğu genç deneyimsiz uzmanlar çalıştırmak istememektedirler.

5. Mevcut işgücü piyasasındaki durumun bir sonucu olarak gençler arasında çalışma motivasyonunun azalmasi.

6. Genç nüfusun istihdamı için istihdam hizmetinin faaliyetlerinde gerekli parasal ve program tabanının olmamas1.

Daha önce de belirtildiği gibi, Rusya'nın gençlik segmentindeki modern işgücü piyasası, yüksek düzeyde gerçek işsizlikle karakterize edilirken, imalat sektöründe vasıflı işçiler için yüksek bir talep ve piyasada talep gören meslekler ile bazılarında mesleki eğitimin uygulandığı kurumlar arasında bir dengesizlik bulunmaktadır. 2019'da en çok talep gören meslekler teknik uzmanlık alanlarında olup; mühendisler, BT (Bilgisayar Teknolojileri) uzmanları, robotik uzmanları, tasarım mühendisleridir. Risk yöneticilerine, iş analistlerine ve proje yöneticilerine olan talep artmaktadır (https://vogazeta.ru/).

Mavi yakalı işler arasında çilingir, elektrikçi, kaynakçı ve makinistlere olan talep de artmaktadır. Eğitim kurumlarında genç uzmanlar için gerekli temel deneyimi elde etmek için staj organizasyonu, artan bir hızda daha az etkili hale gelirken, eğitim ile işgücü piyasasının talebi ve ekonomi arasındaki boşluk giderek artmaktadır. Eğitim kurumlarından mezun olanların çoğu için, istihdamın birincil istihdam piyasasındaki önemi ciddi bir sorun oluşturmaktadır. Genellikle, her hangi bir eğitim kurumlarından mezun olanların deneyimsiz oldukları için bir iş bulmanın son derece zor olduğunun farkında olmaları (aynı zamanda deneyim ancak iş bularak kazanılabilir) onları endişelendirmektedir. Öğrenciler üniversitedeki eğitimleri sırasında bile çeşitli şekillerde iş bulmaya çalışmaktadırlar. Gençler arasındaki bu eğilim, akademik performanslarını olumsuz etkilemekte ve öğrencilerin istihdamının bir sonucu olarak dersleri kaçırdıkları ve çalışmalarına önemli ölçüde daha az zaman ayırdıkları için bilgi kalitesini ve seviyesini düşürmektedir (Çuprov, 2000:118).

Bu sorunu analiz eden Çalışma ve Sosyal Koruma Bakanlığı Başkanı Topilin, Şubat 2016'da diploma aldıktan sonra iş bulamayan öğrencilere eğitim kurumlarını işsizlik yardımı ödemeye mecbur etmek için bir teklifte bulunmuştur. Ancak bu girişim sonucunda bugüne kadar her hangi bir gelişme yaşanmamıştır. Ek olarak, Bologna süreci çerçevesinde Rusya'da yürütülen yüksek öğretim sistemi reformu, birçok işverenin anlayışında bir uzmanın mezunları ile tamamen eşitlenemeyen lisans derecesine sahip uzmanların istihdamında bir dizi ek zorluk yaratmasina neden olmuştur (https://vogazeta.ru/).

En yüksek işsizlik oranları ekonomik olarak aktif nüfusunun \%28'ni oluşturan 20 yaşın altındaki en genç yaş grubunda görülmektedir. Genç işsizliği düzeyindeki en büyük artışın ekonomik kriz dönemlerinde (1998, 2008: 2014-2015) meydana geldiği ve bu göstergenin değeri ne kadar yoğun arttıkça işsizlerin yaşı da o kadar genç olduğu unutulmamalıdır. Genç işsizliği sorunu sadece Rusya'da değil, diğger ülkelerde de mevcuttur. Dolayısıyla, Kuzey Avrupa'nın en müreffeh ülkelerinde bile (Norveç, Danimarka, İsveç, Finlandiya ) ortalama işsizlik oranı \%4-6 olup, genç işsizliği ise \%20'dir. Gençlerin istihdamındaki sorunlar, nitelik becerileri ve mesleki deneyim eksikliği nedeniyle daha da ağırlaşmaktadır. Bu nedenle Rosstat verilerinin analizi, işsiz gençler arasında iş deneyimi olmayanların payının yaklaşık \%79 olduğunu göstermektedir. Bu nedenle, işveren genellikle genç uzmanlara ek eğitim vermek, onları belirli bir risk ve ek finansal yatırımlar gerektiren faaliyetlerine uyarlamak 
zorundadır (Kolmakova ve Korçagina, 2016:35-70).

Sosyolojik araştırmalara göre, lisans mezunlarının \%62'sine ve orta mesleki eğitim mezunlarının \%48'ine göre genç uzmanlara iş sağlamayı reddetmenin en yaygın nedeni pratik deneyim eksikliğidir. Genellikle, potansiyel bir iş yeri seçerken, mezunlar, mesleki niteliklerine aşırı değer verilen bir özgüven ve pratik deneyim eksikliği ile birlikte, genç uzmanların istihdam sorununu daha da kötüleştiren yüksek düzeyde ücretlere yönelmeleridir.

Bir yandan ülkede nitelikli personel sıkıntısı yaşanırken, diğer yandan da uzmanlıkları talep edilmeyen yeni insan grupları ekonomi piyasasına girmektedirler. Bu sorun yalnızca Rusya'da değil, Uluslararası Çalışma Konferansı'nın yıllık raporlarında da aktif olarak tartışılan Batı için de geçerli olmuştur. Gençler, işgücünün en hareketli kısmı olup, işgücü piyasası koşullarına hızlı bir şekilde adapte olabilmektedirler. Bu, bazı durumlarda işçileri işe almak için önemli bir tercih sağlamaktadır. Ayrıca açık pozisyon ilanlarda, kural olarak 30 yaş altı kişilerin iş başvuruları yapılmaktadır. Bu nedenle, şu anda Rusya'da genç işçiler için istihdam firsatları, daha yaşlı ve daha deneyimli çalışanlara kıyasla önemli ölçüde yüksek olmaktadır (Parfyonova, 2017: 40-80).

\section{GENÇLERIN IŞGÜCÜ PIYYASASINDA EĞITTIM, İSSSIZLİK VE ISTIHDAMLA İLGILİ SAYISAL GÖSTERGELERİ}

Rusya'daki genç işsizliğinin ve istihdamın doğasını ve kapsamını yansıtan nicel göstergelere ve Federal Devlet İstatistik Servisi'nin (Rosstat) metodolojisine göre gençlerin yaş aralığı 15-29 yaş aralığında belirlenmektedir. Gençlik; yaş, eğitim seviyesi ve mesleki becerilerine göre işsizlikten koruma dereceleri bakımından farklılık gösteren üç ana alt gruba ayrılmış bir sosyal yaş grubudur (Kapelyuşnikov, 2014: 51-63).

İlk alt grup, 15 ila 19 yaş arası gençleri içermektedir. Bunlar, ekonomik olarak aktif olmayan nüfusa ait bu yaş grubunun nüfusunun \%92'si oluşturmakta olup, esas olarak ortaokul ve ilköğretim mesleki eğitim kurumlarının öğrencileridirler. Nüfusun yaşam standardındaki düşüş, bu genç grup kategorisinin bazı temsilcilerinin çalışma arzusuna sahip olmasına neden olmaktadır. Bu gruptakiler esas olarak serbest çalışmaktadırlar (araba yıkama ve gazete ticareti vb. gibi). İkinci alt gruptakiler ise, 20-24 yaş arası, mesleki eğitim gören veya eğitimlerini tamamlamış öğrenci gençleri içermektedir. Bu alt grup, iş gücü piyasasına giren herkes arasında işsizliğe karşı en savunmasız olanlardır. Çünkü temsilcileri gerekli mesleki deneyime sahip olmamakla birlikte rekabet güçleri de önemli ölçüde azalmaktadır. Üçüncü alt grup, esas olarak belirli bir düzeyde niteliklere ve iş deneyimine sahip olan 25-29 yaş arası gençleri içermektedir. Bu gruptakilerin çoğu mesleki tercihler oluşturmuşlardır. Çoğunluğunun aileleri vardır ve ücret ile çalışma koşulları konusunda yüksek talepleri bulunmaktadır (Korçagina, 2016:1-11).

Modern Rus işgücü piyasası modeli, istihdam edilen nüfusun oranındaki düşüş ve genç işsizliğin ekonomik konjonktürdeki değişikliklere keskin bir şekilde tepki verdiği için gençleri büyük ölçüde etkileyen işsizlik oranındaki artış ile karakterize edilmektedir. Rusya Federasyonu İstatistik (Rosstat) verilerine göre 2014 yılı sonunda 15-29 yaş arası 28,67 milyon vatandaş, ülkenin toplam nüfusunun yaklaş1k \%20'si Rusya Federasyonu'nda yaşamaktaydı. Aynı zamanda Rusya'da 29 yaş altı işsizler toplam işsiz sayısının \%40,3'nü oluşturmuşlardır (Kolmakova, 2016: 31-65).

Genel olarak, 1992-2014 için gençlik alt grupları arasında işsizlik oranı aşağıdaki (Şekil 1) gibidir;

- 20 yaşın altındaki bir grupta: \%20,4'ten \%28'e,

- 20 ila 24 yaş arası grupta: \%9,7 ila \%12,4,

- 25 ila 29 yaş arası grupta: $\% 5,5$ ila $\% 5,6$, olmuştur. 
Şekil 1. 1992-2014 Yıllarında Rusya Federasyonu İşsizlik Oranı (Karşılık Gelen Yaş Grubunun Ekonomik Olarak Aktif Nüfusunun Yüzdesi Olarak)

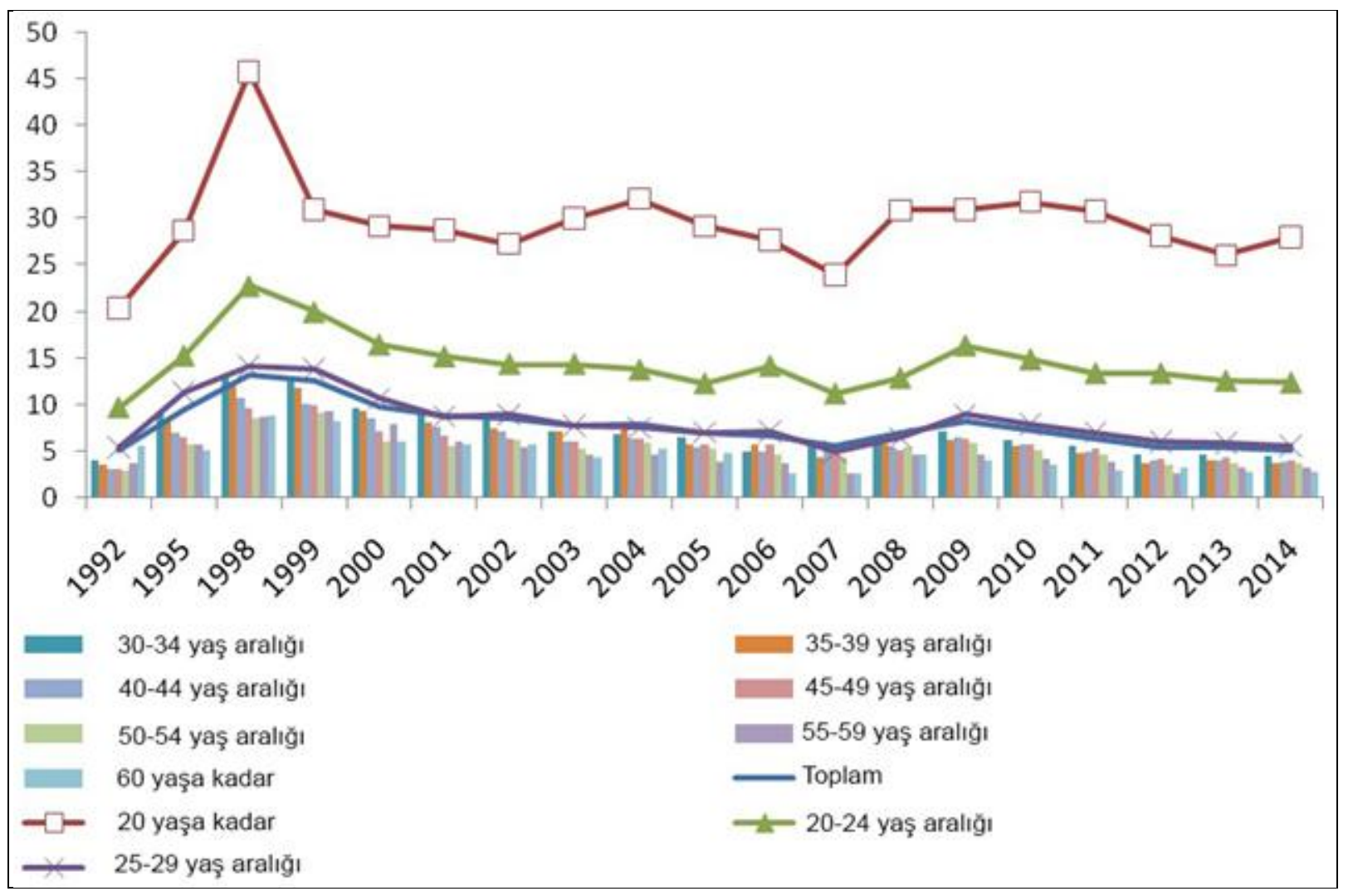

Kaynak: https://rosstat.gov.ru/ (Erişim Tarihi: 03.11.2020).

Rosstat'a göre Eylül 2019'da Rusya'daki işsizlik oranı (işsiz sayısının işgücü sayısına oranı) bir ay öncekine göre $\% 4,3$ 'ten sonra $\% 4,5$ olmuştur. Eylül 2019 'daki işsizlik oranı (işsiz sayısının işgücü sayısına oranı) hem 15 yaş ve üstü nüfus için, hem de 15-72 yaş arası nüfus için \%4,5 olmuştur. Böylece işsizlik oranı Temmuz değerlerine dönmüştür. Mayıs ayında oran \%4,4, Nisan ve Mart aylarında \%4,5, Şubat ayında \%4,7 ve Ocak ayında $\% 4,9^{\prime}$ du. Eylül 2019'da 15 yaş ve üstü çalışanların sayısı 75,6 milyon kişiydi. Bunların 72,2 milyonu ekonomik faaliyetlerde istihdam edildi. 3,4 milyon kişi ILO kriterlerini karşılayarak işsiz olarak sınıflandırılmıştır (ör. bir işi veya karlı bir mesleği yoktu, bir iş arıyordu ve anket yapılan haftada işe başlamaya hazırdı). Eylül 2019'da istihdam oranı (çalışan nüfusun 15 yaş ve üstü toplam nüfusa oranı) \%59,6 olmuştur. Raporlama ayının sonunda, Rostrud'a (Rusya Emek ve İstihdam Federal Hizmeti) göre, istihdam hizmetine 666 bin kişi işsiz olarak kaydolmuştur. Bu Ağustos 2019'a göre \%6,5 ve Eylül 2018 ayına göre \%2,5 daha fazla olmuştur. Eylül 2019 'da 15 yaş ve üzeri işsizler arasında, kadınların payı \%46,8; kent (şehir) sakinleri \%67,7; 25 yaş altı gençler $\% 22,7$; iş deneyimi olmayanlar \%23,5 olmuştur. Kırsal kesimde yaşayanlar arasındaki işsizlik oranı \%6,3 iken, kentlerde yaşayanlar arasındaki işsizlik oranını \%3,9 olmuştur (https://www.eg-online.ru/).

Sonuç olarak, gençlerin sektörel istihdamının yapısı önemli değişikliklere uğramıştır. Sanayideki işçi sayısı azalmış, aynı zamanda tersi bir süreç ticaretteki istihdamda yaşanmıştır. Yani gençler, ticaret alanında tüm çalışanların içindeki yeri en büyük payı oluşturmaktadır. 2002 ve 2014 yıllarında Rusya'da istihdamın sektörel olarak yaşadığı değişiklikler Şekil 2'de göstermektedir (Kolmakova, 2016: 31-65). 
Şekil 2. Rusya Federasyonu Nüfusunun Bireysel Yaş Gruplarına Göre İstihdamının Sektörel Yapısı (\%)

\begin{tabular}{|c|c|c|c|c|c|c|c|c|c|c|c|}
\hline \multirow{2}{*}{20} & \multirow{2}{*}{20} & 9 & 9 & 8 & 9 & 6 & 7 & 5 & 6 & 5 & 4 \\
\hline & & 10 & 11 & 11 & 10 & 10 & 9 & 11 & 9 & 13 & 10 \\
\hline 5 & $\begin{array}{l}4 \\
2\end{array}$ & 7 & 7 & 8 & 9 & 8 & 11 & 8 & 11 & 12 & 14 \\
\hline 23 & 23 & 22 & & 19 & 7 & 14 & 9 & 12 & 10 & 7 & 12 \\
\hline $\begin{array}{l}3 \\
6\end{array}$ & 4 & 8 & & 10 & & 8 & & 8 & 10 & 0 & 11 \\
\hline & & 6 & 10 & 7 & 10 & 13 & 10 & 11 & 7 & 21 & 5 \\
\hline 21 & 29 & 0 & 9 & 10 & 9 & & 总 & & 9 & & 16 \\
\hline 20 & 9 & 28 & 19 & 25 & 20 & 29 & 21 & 32 & 24 & 29 & 20 \\
\hline 2002 & 2014 & 2002 & 2014 & 2002 & 2014 & 2002 & 2014 & 2002 & 2014 & 2002 & 2014 \\
\hline 20 yaş & kadar & $20-2$ & yaş & $30-3$ & yaş & $40-4$ & yaş & $50-5$ & yaş & 60 yaş & usta \\
\hline & Endo & & & & & & W Kir ve & rman sar & ayisi & & \\
\hline & E İnsaa & & & & & & = Nakliy & ve iletişi & & & \\
\hline & $=$ Ticar & ve gıda & ektörū & & & & 플 Saḡlık & & & & \\
\hline & Eğitin & & & & & & Finans & al faaliyet & & & \\
\hline & = Yónet & & & & & & & & & & \\
\hline
\end{tabular}

Kaynak: https://rosstat.gov.ru/ (Erişim Tarihi: 03.11.2020).

Rusya'da eğitim sonucunda ortaya çıkan gençlik yapısı; işgücü piyasasının mesleki ve niteliksel yapısındaki değişikliklere esnek bir tepki göstermeyen, insan sermayesine yatırımın potansiyelini tam olarak anlamayan durum ortaya koymaktadır. Bütün bunlar, işgücünün yüksek kalitede yeniden üretim eksikliğine yol açmış olup; özellikle genç uzmanların neredeyse hiç yer almadığı üretim alanında görülmektedir (Kolmakova, 2016:30-75).

2015 yıl sonu verilerine göre işsizlerin durumuna bakıldığında 25 yaşın altındaki gençler \%23,8; 15-19 yaş arasındakiler \%4,7; 20-24 yaş arasındakiler \%19,1 olmuştur. Yüksek işsizlik oranı 15-19 yaş aralığında olan gençlerde $\% 35,4 ; 20-24$ yaş grubundakilerin ise işsizlik oranı $\% 14,1$ olmuştur. Ortalama olarak, $15-24$ yaş arası gençler arasında Aralık 2015'teki işsizlik oranı \%16,0 olmuş, kentsel nüfus işsizliği \%14,5; kırsal nüfus işsizliği ise \%19,9 olmak üzere olarak gerçekleşmiştir. Yaş gruplarına göre işsizlik oranlarına baktığımızda 15-24 yaş grubu içindeki gençlerin işsizliği, 30-49 yaş arası nüfusun işsizlik oranına göre 3,3 defa, şehir işsizlik oranına göre 3,5 defa, kırsal işsizlik oranına göre ise 2,7 defa daha fazla olduğu görülmektedir (Korçagina, 2016:1-11).

Son y1lların eğitim dinamikleri, gençlerin ekonomik faaliyetlerinde ve istihdamında önemli ayarlamalar yapıldı̆̆ını göstermektedir. 1990'ların ortalarından bu yana, mesleki eğitim sistemi, okul mezunlarının ve ailelerinin ihtiyaçlarının özelliklerine göre gelişmektedir. Bu, farklı mesleki eğitim seviyelerinde öğrenci sayılarının dinamiklerine de doğrudan yansımıştır. Yüksek Mesleki Eğitim kurumlarındaki (YME) öğrenci sayısı keskin bir şekilde artmıştır. Orta Mesleki Eğitimdeki (OME) öğrenci kontenjanında hafif bir artış olmuş ve İlk (Temel-Başlangıç) Mesleki Eğitim kurumlarında (IMME) ise öğrenci sayısı azalmıştır (Korçagina, 2016:1$11)$. 
Şekil 3. 1990-2013 Yılları Arasında Rusya Federasyonu'ndaki Mesleki Eğitim Kurumlarındaki Öğrenci Sayısı

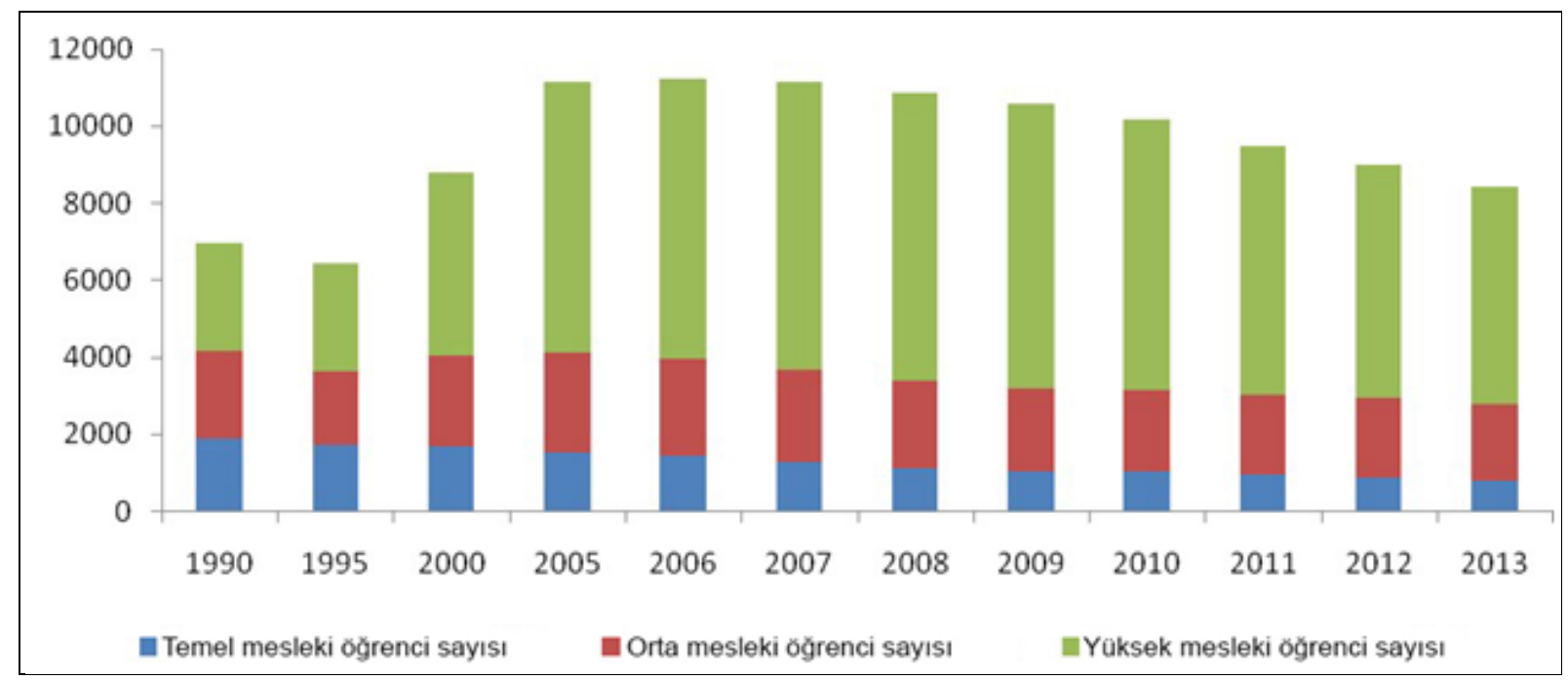

Kaynak: https://rosstat.gov.ru/ (Erişim Tarihi: 03.11.2020).

1990-2013 dönemi için Temel Mesleki Eğitim kurumlarındaki öğrenci sayısı 1.867 bin kişi azalarak, 2013 y1lına gelindiğinde ise 774 bin kişiye düşmüştür (yaklaşık \%41,5 düşüş). Aksine yüksek öğrenim gören öğrenci sayısı 2.824,5 binden 5.646,7 bine (neredeyse 2 katına) çıkmıştır. Orta mesleki eğitim kurumlarındaki öğrenci sayısı ise 2.270 bin kişiden 1.984 .3 bin kişiye gerilemiştir. Bu rakamlar, yaklaş1k \%12,5 düşüş olduğunu göstermektedir (Korçagina, 2016:1-11).

Modern işgücü piyasasında eğitim ve nitelik faktörünün istihdamı ve işte kalmayı nasıl etkilediğine bakalım. İşsizliğe karşı en savunmasız olanlar her zaman temel mesleki eğitime sahip olanlar olmuştur. Orta mesleki eğitim sistemindeki eğitim, yüksek eğitimli olanlar arasında artan işsizliğe karşı bir miktar koruma sağlamıştır. İşgücü piyasasına erken giren gençlerin ikincil işgücü piyasasına girme nedenleri, düşük eğitim kaynakları, istikrarsız, düşük vasıflı, düşük ücretli işler olarak nitelendirilmektedir (Soroçaykin, 2012:160-185).

Şekil 4: Rusya Federasyonu'nda Mesleki Eğitim Düzeyine Göre 2013 Yılı İşsizlik Oranı (\%)

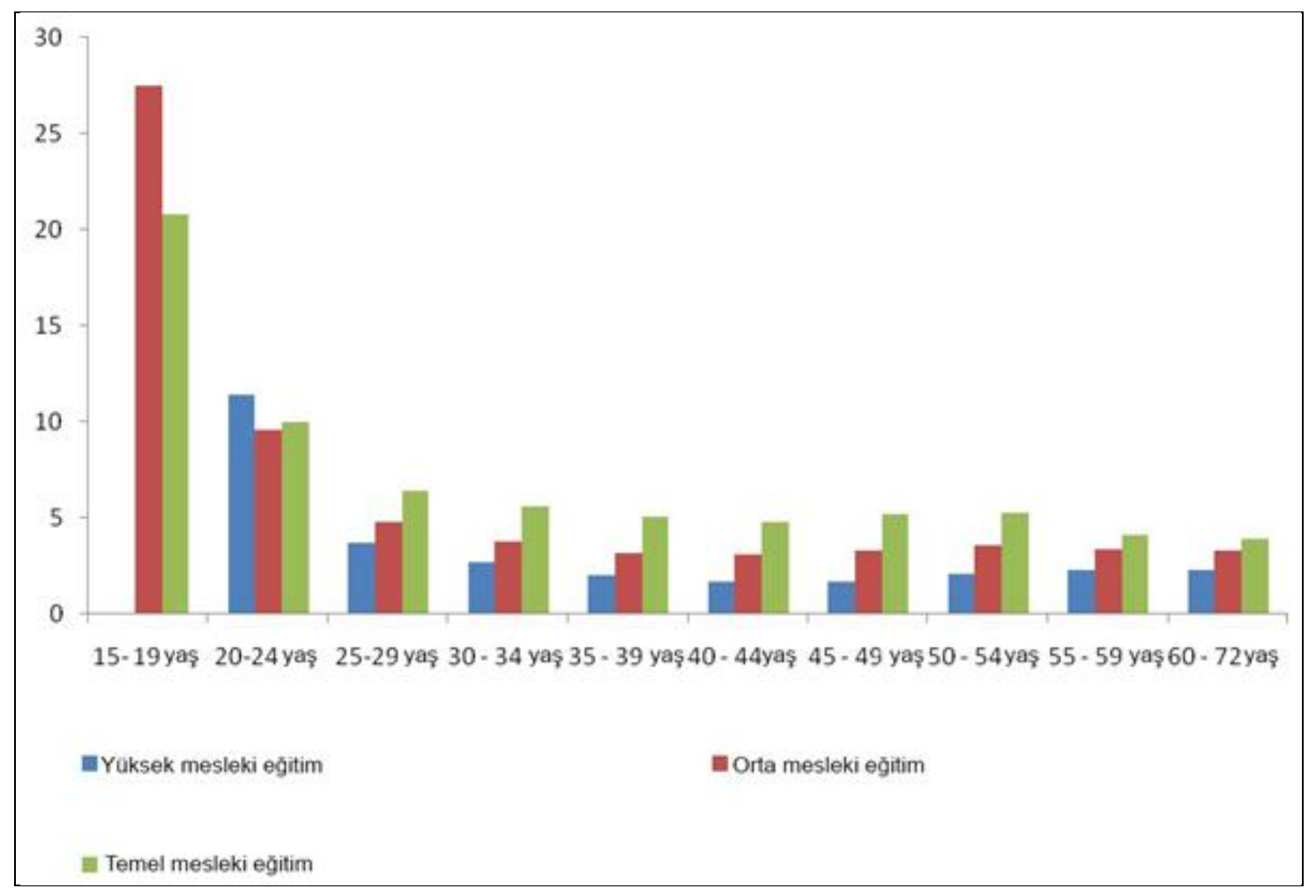

Kaynak: https://rosstat.gov.ru/ (Erişim Tarihi: 03.11.2020). 
Temel mesleki eğitimi olan genç grupları arasında işsizlik oranı 20 yaş altı grupta \%20,8;20-24 yaş grubunda $\% 10$ ve 25-29 yaş grubunda \%6,4 olmuştur. Orta gençlik grubunda yüksek eğitimli insanlar arasındaki işsizlik oranı \%11,5'tir. Bu da büyük ölçüde iş arayanların çoğunluğu arasında istihdam konusunda deneyim eksikliğinden kaynaklanmıştır. Pratik olarak tüm yaş gruplarında yüksek eğitimli daha az işsiz vardır. Bu nedenle daha yaşlı gençlik grubunda yüksek eğitimli insanlar arasındaki işsizlik oranı minimum değere $(\% 3,7)$ sahip olmuştur. $\mathrm{Bu}$, işgücünün en eğitimli kısmının işgücü piyasasındaki avantajlı konumunu göstermektedir (Kolmakova, 2016: 30-75).

Farklı yaşlardaki gençlerin işsizlik oranlarında ortaya çıkan farklılıklar, bu grupların eğitim düzeyleriyle doğrudan ilişkilidir. 0,89 ile 0,95 arasında değişen en önemli korelasyon katsayıları mesleki eğitim almış kişilerde 20 yaş ve üstü yaş gruplarında elde edilmiştir. Temel mesleki eğitim ile ilgili olarak, tersi bir eğilim gelişmektedir. Yaş büyüdükçe katsayıların değeri (en genç grupta 0,6'dan, en yaşlı grupta [60 ila 72 yaş arası] 0,12'ye) düşmektedir (Korçagina, 2016:1-11).

Korelasyon katsayılarına göre yaş arttıç̧a eğitimli kişilerin işsizlik oranındaki düşüşü doğrudan etkilediği görülmektedir. Gençlerin durumuna bakıldığında ise genç yaş gruplarındaki yüksek işsizlik oranları, düşük eğitim ve öğretim seviyeleri ile yakından ilişkili olmaktadır. Kazanılan az miktardaki teorik bilgi ve pratik beceriler, bu yaşta işgücü piyasasına girmeyi zorlaştırmaktadır. Mesleki eğitim alanında meydana gelen değişikliklerin bir sonucu olarak, tabloda sunulan genişletilmiş meslek gruplarına göre istihdam dağılımına ilişkin verilerle de doğrulanan, Rusya nüfusunun istihdamının mesleki ve nitelik yapısı değişmiştir (Korçagina, 2016:1-11).

Tablo 1. Rusya Federasyonu'nda İstihdam Edilenlerin Yapısı (\%)

\begin{tabular}{|c|c|c|c|c|c|c|c|c|c|c|}
\hline \multirow{2}{*}{$\begin{array}{c}\text { Nüfus } \\
\text { (Yaş) }\end{array}$} & \multicolumn{2}{|c|}{ Yöneticiler } & \multicolumn{2}{c|}{$\begin{array}{c}\text { Üst düzey } \\
\text { uzmanlar }\end{array}$} & \multicolumn{2}{c|}{$\begin{array}{c}\text { Orta düzey } \\
\text { uzmanlar }\end{array}$} & \multicolumn{2}{|c|}{ Nitelikli işçiler } & \multicolumn{2}{|c|}{ Vasıfsız işciler } \\
\cline { 2 - 12 } & $\mathbf{2 0 0 2}$ & $\mathbf{2 0 1 4}$ & $\mathbf{2 0 0 2}$ & $\mathbf{2 0 1 4}$ & $\mathbf{2 0 0 2}$ & $\mathbf{2 0 1 4}$ & $\mathbf{2 0 0 2}$ & $\mathbf{2 0 1 4}$ & $\mathbf{2 0 0 2}$ & $\mathbf{2 0 1 4}$ \\
\hline $\mathbf{2 0}$ yaşa kadar & 0,1 & 0,0 & 0,2 & 0,0 & 1,8 & 0,4 & 3,1 & 0,4 & 5,2 & 1,8 \\
\hline $\mathbf{2 0 - 2 9}$ yaş & 11,3 & 13,0 & 21,2 & 24,7 & 23,6 & 24,1 & 21,4 & 22,5 & 19,9 & 19,9 \\
\hline $\mathbf{3 0 - 3 9}$ yaş & 24,4 & 26,9 & 26,5 & 29,0 & 27,0 & 27,0 & 22,6 & 26,7 & 20,6 & 21,5 \\
\hline $\mathbf{4 0 - 4 9}$ yaş & 34,1 & 28,6 & 30,4 & 23,3 & 29,0 & 24,1 & 30,7 & 23,3 & 29,8 & 21,6 \\
\hline $\mathbf{5 0 - 5 9}$ yaş & 24,5 & 26,4 & 16,7 & 18,7 & 15,6 & 20,7 & 15,8 & 23,2 & 17,3 & 26,9 \\
\hline $\mathbf{6 0}$ yaş üstü & 5,7 & 5,2 & 5,0 & 4,2 & 3,1 & 3,7 & 6,5 & 4,0 & 7,1 & 8,3 \\
\hline TOPLAM & $\mathbf{1 0 0}$ & $\mathbf{1 0 0}$ & $\mathbf{1 0 0}$ & $\mathbf{1 0 0}$ & $\mathbf{1 0 0}$ & $\mathbf{1 0 0}$ & $\mathbf{1 0 0}$ & $\mathbf{1 0 0}$ & $\mathbf{1 0 0}$ & $\mathbf{1 0 0}$ \\
\hline
\end{tabular}

Kaynak: https://rosstat.gov.ru/ (Erişim Tarihi: 03.11.2020).

2014 yılı esas alınarak toplamda Rusya'da istihdam edilen toplam genç sayısındaki artış 2002 yılına göre \%2,5 olduğunu görmekteyiz. Ayrıca 20 yaş altı grupta istihdamda 3,5 kattan fazla azalma olmuştur. Bu azalma, en büyük ölçüde orta ve düşük beceri düzeyindeki çalışanları etkilemiştir. Orta yeterlilik seviyesindeki uzmanlar 4,5 kattan fazla, kalifiye işçiler 7,8 kat, niteliksiz işçiler -2,9 kat azalmıştır. En yüksek yeterlilik düzeyine sahip yönetici ve uzmanların payı, mesleki eğitim düzeyine karş11ık gelen 20-29 yaşlarında olduğunu görmekteyiz. Aynı zamanda 2002 yılına göre 2014 yılında uzman sayısında ortalama \%15-16 oranında hafif bir artış olmuştur. Nitelikli personele yönelik istikrarlı talep, büyük ölçüde ekonomideki teknolojik yeniliklerin personelin bilimsel potansiyelinin rolünü artırmasından kaynaklanmıştır (Korçagina, 2016:1-11).

2007-2017 yıllarındaki verilere göre Rusya'da istihdam oran1 \%5 artmış, işsizlik oranı ise \%2,2 düşmüştür. Bu nedenle, vurgulamak gerekir ki, kırsal kesimin işgücü yapısında ortaya çıkan olumsuz eğilim istihdam seviyesini azalmasına neden olmuştur. 
Tablo 2. 15-72 Yaş Arası Çalışanların Yaş Gruplarına Göre Yapısı

\begin{tabular}{|c|c|c|c|c|c|c|}
\hline $\begin{array}{c}\text { YAS } \\
\text { GRUPLARI }\end{array}$ & \multicolumn{7}{|c|}{ YILLAR } \\
\hline $\mathbf{2 0 0 0}(\mathbf{\%})$ & $\mathbf{2 0 1 3}(\mathbf{\%})$ & $\mathbf{2 0 1 4}(\mathbf{\%})$ & $\mathbf{2 0 1 5}(\mathbf{\%})$ & $\mathbf{2 0 1 6}(\mathbf{\%})$ & $\mathbf{2 0 1 7} \mathbf{\%})$ \\
\hline $15-19$ & 1,8 & 0,7 & 0,6 & 0,6 & 0,6 & 0,5 \\
\hline $20-24$ & 9,5 & 8,5 & 7,8 & 7,0 & 6,4 & 5,7 \\
\hline $25-29$ & 13,0 & 14,2 & 14,5 & 14,5 & 14,5 & 14,4 \\
\hline $30-34$ & 12,6 & 13,2 & 13,5 & 13,9 & 14,3 & 14,6 \\
\hline $35-39$ & 11,6 & 12,7 & 12,8 & 13,0 & 13,2 & 13,6 \\
\hline $40-44$ & 12,6 & 11,6 & 12,0 & 12,2 & 12,5 & 12,7 \\
\hline $45-49$ & 14,7 & 12,3 & 11,8 & 11,4 & 11,2 & 11,4 \\
\hline $50-54$ & 12,4 & 13,3 & 13,3 & 13,0 & 12,7 & 12,1 \\
\hline $55-59$ & 7,9 & 8,8 & 9,0 & 9,3 & 9,4 & 9,6 \\
\hline $60-72$ & 3,8 & 4,7 & 4,8 & 5,1 & 5,3 & 5,3 \\
\hline Ortalama & 39,9 & 40,3 & 40,4 & 40,6 & 40,7 & 40,8 \\
\hline & & & & & & \\
\hline
\end{tabular}

Kaynak: Abdullah, 2020.

Tablo 2'ye göre, 15-72 yaş arası çalışanların sayısında 2007 yılından 2017 yılına kadar geçen dönemde önemli değişiklikler olmuştur. Böylece, 15-19 yaşları arasındaki istihdam edilen nüfus $\% 1,3$ azalarak $\% 1,8$ 'den $\% 0,5$ 'e düşmüştür. "55-59" yaş grubunda ise bu oran \%1,7 artmıştır. Bununla birlikte, önemli değişikliklerin olmadığ 1 yaş grupları vardır. Örneğin, 40-44 yaş grubu arasında, 10 yaş üstü bu oran \%12,6'dan \%12,7'ye yükselmiştir (sadece \%0,1). Böylece, 2007-2017 dönemi için yaş ölçütüne göre istihdam yapısında bir değişiklik olduğu sonucuna varabiliriz. 40 yaşındaki istihdam edilenlerin sayısı artmış ve genç nüfusun istihdamı 25 yıla düşmüştür. Yaş ortalamas 2017 yılında 40,8 istihdam 2007'ye göre 0,9 yaş artmıştır (Abdullah, 2020: 22-25).

\section{SONUÇ}

Modern ekonomideki bilgi yoğun endüstrilerin "lider pozisyonları - bilgi teknolojisi”, "finans", "bilimsel ve teknik endüstriler", çalışanların yüksek kalitede mesleki ve profesyonel eğitimini gerektirmektedir. Bu nedenle, işçilerin eğitim düzeylerini iyileştirme ihtiyacı, modern ekonomide mesleki eğitime olan talep azaltmayıp, aksine artmasını sağlamaktadır. Ekonomik açıdan beşeri sermaye birikimi, işçilerin rekabetçi konumunu güçlendirmekle, işgücü piyasasındaki konumlarını önemli ölçüde iyileştirmektedir. Bu da kazançların artmasına, çekici ve daha cazip mesleklere, işlere erişimi genişletmekte ve işsizlik riskini azaltmaktadır. Yüksek eğitim seviyesine sahip gençlerin rekabet avantajlarının büyümesi, yalnızca modern ekonominin gelişiminin yenilikçi doğası ile değil, aynı zamanda bu tür çalışanların daha fazla uyarlanabilirliği, yeni emek faaliyet türlerine hızla hâkim olma yetenekleri ile de açıklanmaktadır.

Genç istihdamının sektörel yapısında ekonomik faaliyet türüne göre aşağıdaki eğilimler gelişmiştir. Rosstat verilerine göre, maddi üretim alanında (esas olarak sanayi, inşaat, ulaşım) işçi sayısında azalma mevcut olup, bunun sonucunda da gençlik kesiminde işsizlik oranlar çok daha yüksek olmaktadır. Aynı zamanda bazı maddi olmayan üretim sektörlerinde (finans, ticaret, yönetim) ise işçi ve çalışan sayısında artış gözlemlenmektedir.

Günümüzde işgücü piyasasının küreselleşme süreçlerinin bir sonucu olarak girişimciliğin gelişmesi, bölgeler veya ülkeler arası seyahatin rahat ve serbest olması gençlerin mesleki seçiminde daha özgür hale gelesine olanak sağlamıştır. İstihdam edilen gençlerin sektöre göre dağılımı, her şeyden önce post endüstriyel ekonominin gelişme eğilimleriyle belirlenmektedir.

Rus genç işgücü piyasasının gelişimi, büyük ölçüde, nüfusun istihdamını artırmayı amaçlayan devlet desteğinin düzeyine ve sosyal politikanın uygulanmasına bağlıdır. Rusya'da genç istihdamı için devlet desteği sistemi, diğer problemlerin yanı sıra gençliğin sorunlarını da yansıtan, nüfusun istihdamını teşvik etmek için federal ve bölgesel programların geliştirilmesini ve uygulanmasını içermektedir. Rusya'da Federal Gençlik İşleri Ajansı tarafindan uygulanan bir dizi hedef program, gençlerin işgücü piyasasındaki konumu üzerinde önemli bir etkiye 
sahip olmaktadır; "Sen bir girişimcisin","Genç Beyinler - Yeni Fikirler". Kırsal kesimdeki gençliğe destek ise, "Kırsal Alanların Sürdürülebilir Kalkınması" federal hedef programı çerçevesinde yürütülmektedir.

Rusya Federasyonu'nda işsizlikle mücadele sosyal politika çerçevesinde yürütülmekte olup, ekonominin ihtiyaçlarının karşılanmasında kalifiye personelin istihdamına daha az özen gösterilmektedir. Mesleki eğitim kuruluşları Eğitim Bakanlığı'nın yetkisi altında olup, istihdam kuruluşları ise Rusya Federasyonu Sağlık ve Sosyal Kalkınma Bakanlığı'nın yetkisi altındadır. Bu nedenle, eğitim kurumlarının bugün zaten yeterince var olan hukuk ve ekonomi uzmanlarının yetiştirilmesi talebinin yanında işgücü piyasasının ihtiyaçlarını karş1layabilecek teknik uzmanlar ve vasıflı işçiler yetiştirmesi daha uygu olacaktır.

Özellikle genç istihdamı, işgücü piyasası ve mesleki eğitim arasındaki yakın bağların olmaması nedeniyle zorluklar yaşamaktadırlar. İşgücü piyasasını optimize etmek için mesleki eğitim sisteminde yer alan süreçlerin düzenlenmesi için, ticari kuruluşlar, devlet teşebbüsleri ve mesleki eğitim kurumları ile sözleşmeler yaparak kalifiye ve uzmanlaşmış eleman ihtiyacı karşılanacaktır.

Eski Sovyet uygulamalarına baktığımızda; öğrenimlerini tamamlayan öğrenciler mezun olduklarında işletmelerde zorunlu olarak çalışmaları için dağıtım yapılmaktaydı. Bu dağıtım sonrası mezunlar birkaç yıllarını bu işletmelerde çalışmaktaydılar. Böyle bir dağıtım sistemi gençlerin istihdam sorununu çözmüş ve işgücü piyasasındaki durumu düzenlemiştir.

Pek çok Avrupa ülkesinde, istihdamı teşvik politikaları ekonomi politikalarının bir parçası olmuştur. İstihdam bürolarının öncelikli görevi, ekonominin ihtiyaçlarını işgücüyle karşılarken, toplumun işsizlik sorunu ile baş etmesine yardımcı olmaktır. Bu durumda, vasıflı işçiler emekliliğe ayrıldıklarında onların yerini gençler arasından yeni uzmanlaşmış olanlarla doldurulması gerekmektedir. Ardından, gençlerin ilgili alanlarda bilgi ve becerileri edinmelerini sağlamak, devlet politikasının öncelikli bir alanı haline gelmiş olacaktır.

Uluslararası Çalışma Örgütü (UÇÖ veya ILO) gençlerin istihdamı ile ilgili sorunların çözümüne çok ciddi önem vermektedir. Genç personelin istihdamını sağlamaya yönelik oldukça kapsamlı bir program olan "Gençlik İstihdam Programı" adı altında, gençlere gelecek vaat eden ve oldukça aktif bir şekilde gelişen bilgi teknolojileri alanında genç girişimcileri destekleyen, onları geliştirmek ve başarılı bir şekilde işe başlatmak için gerekli eğitim ve finansal kaynaklarla destek sağlamaktadırlar.

İşü̈cü piyasasını yönetmenin temel görevlerini çözmek için (işsizlik oranını düşürmenin yanı sıra işgücü arz ve talebi arasında bir denge sağlamak), işgücü piyasası altyapısı gibi önemli bir bileşenin etkin işleyişini de sağlamak gereklidir. Aynı zamanda, genç istihdamını sağlamak için etkili önlemlerin geliştirilmesi, istihdam yetkilileri tarafından gençlerin kayıt altına alınmasına yönelik yöntemlerin ve devlet istatistiklerinin iyileştirilmesinin sağlanması gerektirmektedir. Sadece gençlik işgücü piyasasının durumunu karakterize eden yeni göstergeler geliştirmek değil, aynı zamanda mevcut göstergeleri daha tam olarak uygulamanın yollarını da aramak gereklidir.

Genel olarak, üretken genç istihdamının teşvik edilmesi, bununla ilgili tüm faaliyetlerin tutarlılığını sağlayacak ve genç personelin istihdam düzeyini artırmak için bu duruma Rusya devletinin ekonomik politikasının bir unsuru olarak ele alınması şeklinde bakılması gerekmektedir.

Mevcut (işsizlik ve istihdam) sorunların bir kısmının aşağıda sunulan yöntemlerle çözülebileceği düşünülmektedir. İstihdam için gerekli iş deneyiminin olmaması veya elde etmenin zorluğu; bu sorunu çözmek için en etkili yolu kota sistemidir (norm kadro). Şu anda bu mekanizma tüm kategorilere uygulanmasa da (engelliler, yetimler, çocuk sayısı çok olan ailelerde uygulanmaktadır) bazı kategorilerdeki uygulama sonucu çok düşük seviyede kalmaktadır. Bu sorunun bir başka çözüm yolu da, tek seferlik işlerde geçici işe alma uygulaması ile öğrenciler boş zamanlarını (kısa çalışma-part time) bilimsel araştırmalarda, gönüllülerin sosyal faaliyetlerinde vb. çalışarak deneyim kazanabilirler. $\mathrm{Bu}$ durumda, gençlerin geçici olarak istihdamı, iş deneyimine ek olarak saygı ve itibar kazanmalarını sağlayacaktır. Bu durum, mevcut işgücü piyasası koşullarında çok önemlidir. Ayrıca bu durumdan kurtulmak için eyaletin federal (Federal Bölgelerin) düzeyde gençlere iş yaratma projesi oluşturması mümkündür.

İşe alımlarda kadınlara karşı ayrımcılık sorunu; bu sorunun çözümlerinden biri evde iş kaydı, tek seferlik işler, serbest meslek vb. gibi bir öneri olabilir. Bu, özellikle yüksek niteliklere ve yaratıcı potansiyele sahip ancak iş bulmanın zor olduğu kadınlar üzerinde olumlu bir etkiye sahip olacaktır.

Cinsiyet ayrımcılı̆̆ının önündeki engel ve önyargıyı aşmak için Rusya Federal İstihdam Servisi tarafindan düzenlenen özel eğitimlerin yapılması gerekmektedir. Bunun için etkili bir yol, işe alım ajansları tarafından personel kiralama hizmetlerinin sağlanması olmasıdır. Ancak mevcut vergilendirme koşullarında bu yöntemin 
kullanımı işverenler için karlı olmamaktadır. Bu nedenle bu önerinin uygulanması zordur.

Gençlik işgücü piyasasında arz ve talep dengesizliği; şu anda, tüm genç profesyoneller değişen bir duruma uyum sağlamak gibi bir beceriye sahip olmamaktadırlar. Bunun için bu tür disiplinleri, bu beceriyi sonuna kadar geliştirecek bir uzmanlığı öğretme sürecine sokmak olacaktır. 4-5 yıl için gerekli tüm açık iş hacmini hesaba katan, işgücü piyasasındaki durumu analiz eden ve tahmin eden bir bilgi sistemi oluşturulmuş, ancak tam olarak geliştirilmemiştir. $\mathrm{Bu}$ nedenle iyileştirmeye ve ayrıntılara ihtiyacı vardır. Bu nedenle, Rusya'da işgücü piyasasında ve istihdamda modern gençlik sorunu analiz edildikten sonra, bir sosyal grup olarak gençliğin oldukça zayıf bir işçi kategorisi olduğu sonucuna varmaktayız. Bu da devlet politikasının sorunları olan kontrol sorunlarıdır. Elbette gençlik işgücü piyasasında kriz durumunun tüm çıkış yolları istisnasız olarak hayatımızın sosyal, hukuki, ekonomik ve politik alanlarında engellerle karşılaşmaktadır. Bu nedenle tüm tedbirler bir kompleks içerisinde yapılmalıdır.

Ulusal gençlik politikasını sağlamak için bütçe ödemeleri uygulamasının yeniden başlatılması gerekmektedir. Ancak telafi edici eylemler, zorunlu olarak sınırlandırılmalı, genç uzman ve profesyonelleri desteklemesi gereken kategoriler tarafından açıkça tanımlanmalıdır. Ana eylemler, yatırımları genç nesile çevirmeye odaklanmalıdır. Bu ayar gençlik ve çocuk derneklerine yardım sağlamak için mali kaynakların hesaplanmasında farklı bir yaklaşım izlenmesini gerektirmektedir. Sonuçta, sosyal yatırımların anlamı olumlu sonuçlarını tahmin etmekte yatmaktadir.

\section{KAYNAKÇA}

ABDULlAH, Akif (2020), “Rusya Federasyonu’nda İsgücü Piyasasının Yapısı, Özellikleri ve Sorunları”, İktisadi ve İdari Bilimlerde Güncel Akademik Çalışmalar (Ed. Mustafa Hatipler), Akademisyen Kitabevi, Ankara, ss.15-28.

BATENEVA, Tatyana (2014), “iz Direktorov v Klounı”, Rossiyskaya Biznes - Gazeta: Karyera i menedjment- № 943.

BOBKOV, Nikolay (2014), "Vliyanie Neustoyçivoy Zanyatosti Na Perehodı Molodyoji Na Rinke Truda", Aktualnaya Tema: Neustoyçivost Zanyatosti, Uroven Jizni Naseleniya Regionov Rosii - No: 3, (193).

BRUSYANINA, Mariya (2010), "Sfera Obrazovaniya Kak Institutsional'noye Ogranicheniye Dlya Molodezhi Na Rynke Truda”, Vestnik Tomskogo Gosudarstvennogo Universiteta, №332.

CUPROV, Vladimir ve ZUBOK, Yuliya (2000), "Molodozh'v Obshchestvennom Vosproizvodstve, Problemy I Perspektivy", RITS ISPI RAN.

DUNAYEVA, Nataliya (1998), “Molodezh' na Rynke Truda “Voprosy Ekonomiki: Uchebnoye Posobiye, №1.

GORSKOV, Mihail ve FRANZ, Sheregi (2010), “Trudoustroystvo Molodyoji”, Molodyoj Rossii: Soçiologiçeskiy Portret, ISBN 978-5-98201-021-6.

KAPELYUŞNIKOV, Rostislav (2014), "Rossiyskiy Rynok Truda: Paradoksy Postkrizisnogo Razvitiya“, Voprosy Ekonomiki, №7.

KOLMAKOVA, Liliya ve KORÇAGİNA, Inna (2016), "Sovershenstvovaniye Uchebno-Poznavatel'noy Deyatel'nosti Studentov Kak Osnova Formirovaniya Professional'nogo Samoobrazovaniya”, Voprosy Sovremennoy Nauki: Kollektivnaya Nauchnaya Monografiya, pod red. N.R. Krasovskoy. - M.: Internauka.

KORÇAGINA, Inna (2014), "Problemy Zanyatosti Molodezhi Na Regional'nom Rynke Truda”, Izvestiya Altayskogo Gosudarstvennogo Universiteta: Zhurnal Teoreticheskikh İ Prakticheskikh İssledovaniy.

KORÇAGINA, İnna (2016), "Problemı Funkçionirovaniya Molodejnogo Rınka Truda V Rosii”, NAUKOVEDENIE, ISSN 2223-5167, Том 8, №5.

KOZLOVA, Tatyana (2002), "Otsenka Starshim Pokoleniyem Molodezhi”, Filosofiya Starosti: Gerontosofiya. Seriya "Symposium", Vypusk 24. Sbornik Materialov Konferentsii, Sankt-Peterburg: Sankt- Peterburgskoye Filosofskoye Obshchestvo.

LUÇANKİN, Aleksandır (1997), "Sotsialno - Klubnaya Rabota S Molodezh'yu”, Problemy i Podkhody, Yekaterinburg.

PARFYONOVA, Valeriya (2017), “Bezrabotitsa Sredi Molodezhi”, Nauchno-Obrazovatel'nyy Potentsial 
Molodezhi V Reshenii Aktual'nykh Problem XXI Veka, ISSN:2410-986X, № 7.

RUÇKIN, Boris (2000), "Molodezh' Rossiyskoy Federatsii”: Polozheniye, Vybor Puti, Osnovnyye Vyvody i Predlozheniya.

SEMENOVA, Yuliya (2016), "Analiz Bezrabotitsy Sredi Molodezhi”, Obrazovaniye i Nauka Bez Granits: Sotsial'no-Gumanitarnyye Nauki, № 5.

SOROÇAYKİN, Andrey (2012), "Teoreticheskiye Osnovy İssledovaniya Zanyatosti Naseleniya V Sovremennoy Rossii”, Ekonomika i Upravleniye v XXI Veke, T. 10. Upravleniye Personalom: Kollektivnaya Monografiya / Pod Obshch. Red. A.N. Sorochaykina. - Samara: Izdatel'stvo «Samarskiy universitet».

STIGLIÇ, Djozef (2005), "Semena Razvala", Revushchiye Devyanostyye: Sovremennaya Ekonomika İ Pravo.

SULAKŞİN, Stepan (2015), Politiçeskaya Platforma Buduşey Partii, Tsentr Nauchnoy Politicheskoy Mysli İ İdeologii, Nauka İ Politika.

SULAKŞİN, Stepan, BAGDASARYAN, Vardan, BALMASOV, Sergey ve BEZRUKOV, Andrey (2016), Rossiya i Mir. Rossiyskiy Mirovoy Proyekt. Tom I, Pod Obshchey Redaktsiyey S.S. Sulakshina. M.: Nauka İ Politika.

YUREVIÇ, Andrey (2012), "Dinamika Psikhologicheskogo Sostoyaniya Rossiyskogo Obshchestva: Ekspertnaya Otsenka", Nravstvennost Sovremennogo Rossiyskogo Obshchestva: Psikhologicheskiy Analiz, Izdatel'- Stvo Institut Psikhologii RAN.

http://www.gks.ru/bgd/free/B04_03/IssWWW.exe/Stg/d06/16.htm (Erişim Tarihi: 03.10.2020).

https://rg.ru/2016/02/05/mintrud-predlozhil-obiazat-vuzy-platit-posobiia- bezrabotnym-vypusknikam (Erișim Tarihi: 03.10.2020).

https://vogazeta.ru/articles/2018/11/6/analitycs/4451-

molodezhnaya_bezrabotitsa_v_rossii_skolko_pochemu_i_opravdana_li_panika (Erişim Tarihi: 03.10.2020). 